Canadian Journal of Educational Administration and Policy
Revue canadienne en administration et politique de l'éducation

CJEAP

\title{
Bridgstock, R., \& Tippett, N. (Eds.). (2019). Higher Education and the Future of Graduate Employability: A Connectedness Learning Approach
}

Darcia Marie Roache

Number 196, 2021

URI: https://id.erudit.org/iderudit/1078523ar

DOI: https://doi.org/10.7202/1078523ar

See table of contents

Publisher(s)

Department of Educational Administration, University of Saskatchewan

ISSN

1207-7798 (digital)

Explore this journal

Cite this review

Roache, D. (2021). Review of [Bridgstock, R., \& Tippett, N. (Eds.). (2019). Higher Education and the Future of Graduate Employability: A Connectedness Learning Approach]. Canadian Journal of Educational Administration and Policy / Revue canadienne en administration et politique de l'éducation, (196), 131-133. https://doi.org/10.7202/1078523ar 
Canadian Journal of Educational Administration and Policy, 196, 131-133

\title{
Bridgstock, R., \& Tippett, N. (Eds.). (2019). Higher Education and the Future of Graduate Employability: A Connectedness Learning Approach. Edward Elgar Publishing. doi:10.4337/9781788972611. Pages. 278. ISBN: 9781788972604.
}

\author{
Reviewed by: Darcia Roache, University of Saskatchewan
}

\section{Introduction}

Higher Education and the Future of Graduate Employability: A Connectedness Learning Approach focuses on how higher education learners can be socially connected while developing their capabilities for employability and networking. The authors' emphasis on connectedness is grounded on the idea that, “... through the learning experience, students interact with others in productive ways, acquire new perspectives, build trust, and develop authentic professional and interest-based communities and networks" (p. 9). These connections form the individual skills that learners acquire, informing the relationships that are important for their future lives (Bridgstock \& Tippett, 2019). The authors stressed the relevance of connectedness to learners by drawing from Argyle (1981) and Friend and Cook's (1992) work, which helps in identifying the learners' pathways to boost their career productivity, improve their confidence, find new opportunities, and support their skills and knowledge.

Higher education has evolved over decades, giving importance to communication, teamwork, and collaboration. Learning has evolved to equip learners with social and technical capabilities or skills that will help them to succeed in their professional lives. The future of graduate employability, in light of connectedness, includes traits such as effective communication, collaboration, and teamwork. Bridgstock and Tippett postulate that these skills have become "ubiquitous in university courses, merging as some of the most valuable, and yet tacit and often difficult to teach, skills that learners from every discipline develop during their time at university" (p. 1). Connectedness is the nucleus of importance to peoples' life by way of health and wellbeing, social change, career development, and learning (Bridgstock \& Tippett, 2019).

\section{Overview}

The relation between the connectedness learning approach, learning in higher education, and graduate employability is contextualised through a series of case studies. The book is the result of a course taught at Queensland University of Technology in 2015-2016, titled: Graduate Employability 2.0. This course was part of an Australian National Senior Teaching Fellowship. It culminated in a Connectedness Learning Roundtable (December 2017) with the chapters in the book showcasing research by the participants. The book consists of three parts: Part one deals with connectedness capabilities. Connectedness capabilities connect individuals to lives, careers, and work in the form of collaboration, communication, and cooperation applicable for social interaction and learning in higher education (Bridgstock \& Tippett, 2019). 
Part two addresses connectedness as pedagogies. Connectedness pedagogies in higher education analyses how universities foster learners' professional networks through integrated learning methodologies (Bridgstock \& Tippett, 2019). Part three focuses on institutional strategies geared towards supporting students' development of life and work. These strategies focus on "how degree programs, organizational areas, such as faculties or division, and universities more broadly can enable connectedness learning" (Bridgstock \& Tippett, 2019, p. 182). The institutional strategies contribute to the enrichment of knowledge and practices among university partners. The book contributes to current academic conversations on learning and employment in higher education by defining connectedness as a blend of several capabilities. These include the knowledge, skills, and attributes required by learners to build, maintain, and form social relations throughout their careers (Bridgstock, 2019a; Forret \& Dougherty, 2001).

Connectedness as pedagogies supports graduates in fostering learning capabilities and examining their learning experiences, supporting their connectedness via face-to-face and through digital platforms in a dynamic and complex society. The book's final section explores institutional enabling strategies for universities to "create, support, and maintain partner, collaborator and network engagement plans and practices to cultivate better connected programs, organisational area and institutions" (p. 185). Structures, processes, teaching staff, curricula, and pedagogic practices can be aligned to support learners' development and their connectedness for life and work.

\section{Thesis and Organization of Chapters}

The collection of chapters reflects the desire to place connectedness at the forefront of research on social change, as career development, learning and teaching, learning and leading in the community of scholar-practitioners. This review provides a general summary of the authors' arguments on learning in higher education and the future of graduate employability from the connectedness learning approach.

Part One, Connectedness Capabilities, comprises four chapters that discuss the role of higher education in preparing students for short-term job outcomes. In this section, Bridgstock and Tippett argue that higher education and the future of graduate employability should not only focus on university education to develop learners' disciplinary and transferable skills, as these no longer grant positive outcomes for learners. Instead, they argue that learners should focus on how they can build, maintain, and form relationships with particular attention on the use of digital platforms and social media. Lupton et al., in Chapter 3, argue that students' professional digital identities in higher education should be supported by educators. As "educators who value connectedness learning are increasingly looking towards the use of networked social media tools and platform to support students in developing their connectedness capabilities and building a professional identity" (p. 30). Scheepers et al., in Chapter 4, explore connectedness capabilities more fully from non-traditional students' pedagogical contexts and implications from a regional university. The authors provide guidelines on how students can educate, build, maintain, and use their social networks to provide equitable and excellent educational development for graduate employability and career connections. Bridgstock et al., in Chapter 5, explore the need for social connectedness and graduate employabilities to form professional networks from a business and creative industries' perspective in higher education. Such networks could ensure employment opportunities, form network capabilities, and foster learning opportunities relevant to strengthen students' employability and career success.

Part Two, Connected Pedagogies, presents five chapters that examine connectedness pedagogies and implications and outcomes in three universities. Brown et al., in Chapter 7, outline an evaluation to integrate connectedness learning in careers and employability within an Australian university. It was recommended that educators and career employability specialists integrate LinkedIn and digital social networks in higher education for learners to support their career identity, professional network connection, and employability. Radoll et al., in Chapter 8, discuss the need for a cultural interface in connectedness learning from an Indigenous and non-Indigenous approach to aid knowing, learning, and connecting. Radoll et al. argued that "connectedness, with people, places and things, is core component of Aboriginal and Torres Strait Islander culture and pedagogy" (p. 97). Goodwin et al.'s research in Chapter 9 discusses the application of connected learning with the use of capstones to consolidate students' learning and to orientate them to the world of work and study. The authors presented recommendations that educators in higher education could use to change their capstone programs to benefit students' authentic and connected learning experience. Finally, Bedford and Bell, in Chapter 10, explore the University of 
Wollongong (UOW) curriculum model to support students' connectedness capabilities that will provide learning experience to support their development for twenty-first-century employability skills. The authors argue that students' future employability can be facilitated if educators assist them in developing social network literacy, brand awareness, and in growing their professional identity while they work with and maintain social and professional connections.

Part Three, Institutional Enabling Strategies, presents four chapters that focus specifically on the importance of connectedness capabilities that graduate students can use in higher education to foster and develop connections and learning. In Chapter 12, Kerr et al. explore collaborative approaches to how educational institutions can support and develop learners' twenty-first-century skills set. They document "the design and delivery of a co-curricular design-led social entrepreneurship program initiated by a secondary school" (p. 187) and university partners, to create learning opportunities. Hammer et al., in Chapter 13, describe an initiative that could be used to integrate programs at the university level to enhance and support educators. Killo et al., in Chapter 14, describe how universities can use systemic enabling strategies for the delivery of connected learning for students in higher education. In general, the authors of the chapters in Higher Education and the Future of Graduate Employability: A Connectedness Learning Approach emphasize the need for connectedness in order to build graduate employability for career, work, learning, and life.

\section{Conclusion}

The book's contribution to connectedness capabilities demonstrates that universities have several ways to support learning that is connected. This approach demands an understanding of students' needs, their existing capacities, the institutional context, and strengths that make capacities to be enhanced and connected. Readers will find Bridgstock and Tippett's (2019) Higher educational and the future of graduate employability: A connectedness learning approach, logically constructed and grounded in strategies and practices for learners, teachers, and educational leaders. The development of educational policies for graduate employability through social connectedness, and the pursuance of a cohort of community, invested with advanced knowledge, and grounded the socially desirable nature of the topics, are new pathways to positive student career development.

\section{References}

Andrew, T. (2012). What is social constructionism? Grounded Theory Review, 11(1), 39-46.

Argyle, M. (1981). Social skills at work. Routledge and Kegan Paul.

Bridgstock, R. (2019a). Graduate employability 2.0: Education for work in a networked world. In J. Higgs, G. Crisp \& W. Letts (Eds.), Education for employability: The employability agenda (pp. 268-282). Sense-Brill Publishers.

Bridgstock, R., \& Tippett, N. (2019). Higher education and the future of graduate employability: A connectedness learning approach. Edward Elgar Publisher.

Forret, M. L., \& Dougherty, T. W. (2001). Correlates of networking behavior for managerial and professional employees. Group and Organization Management, 25(3), 283-311.

Friend, M., \& Cook, L. (1992). Interactions: Collaboration skills for school professionals. Longman Publishing Group.

Shah, M., Grebennikov, L., \& Nair, C. S. (2015). A decade of study on employer feedback on the quality of university graduates. Quality Assurance in Education, 23(3), 262-278. 